\title{
Patent-holders on expert committees. Can there be a conflict of interest?
}

\section{Erik Thorstensen}

\author{
Work Research Institute, Centre for Welfare and Labour Research, Oslo and Akershus \\ University College of Applied Sciences, erik.thorstensen@afi.hioa.no
}

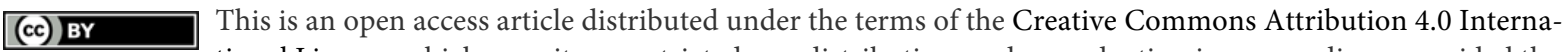 tional License, which permits unrestricted use, distribution, and reproduction in any medium, provided the original author and source are credited.

The presence of experts holding patents and simultaneously providing policy advice on areas in which they hold these patents poses several normative questions. Through a comparative study of several IPCC reports, this article documents the scope of this phenomenon and discusses it with respect to a theory of conflict of interest. A review of IPCC writing teams suggests that the presence of patentholders is largest on issues of infrastructure, industry and transport rather than single technologies. According to insights from studies on conflict of interest, the presence of patent-holders creates an increased risk of bias. This article investigates the possible link between patenting and conflicts of interest, according to theoretical and empirical insights into the relationship between science and society.

Keywords: Expert committees, patents, conflict of interest, IPCC

\section{Introduction}

This paper proposes to look at two parallel and connected issues in order to investigate what kinds of new normative challenges are posed by the use of technologies to solve societal challenges and what kinds of theoretical insights can be used to address one such specific challenge.

One new normative challenge is the issue of intellectual ownership of technologies. More specifically, this is the situation in which patent-holders for technologies are represented on committees providing advice for decision-makers regarding this technology. Parallel to a presentation of data from one case of patent-holders, this article proposes to use insights from the literature on conflicts of interests (CoI) in order to see if such a theoretical apparatus can be productive in solving this normative issue.

This article presents the Intergovernmental Panel on Climate Change (IPCC) as an expert committee. It draws comparisons between different Working Groups (WG) and different types of reports to see if there can be any systematic differences in the presence of patentholders. Furthermore, the article investigates different views on patents and the patent-system in order to analyze whether a theory of CoI can provide guidance for addressing the issue of patent-holders providing advice to governments.

\section{Method}

In determining where to look for patent-holders, this paper and its problem formulation are informed by the Open letter that the ETC Group sent to the Chairman of the IPCC, Rajendra 
K. Pachauri, before the IPCC joint working group expert meeting on geoengineering in June 2011:

The Scientific Steering Group of this expert meeting includes well-known geoengineering advocates who have called for steep increases in funding for research and for proceeding with experimentation, as well as scientists who have patents pending on geoengineering technologies and/or other financial interests. Asking a group of geoengineering scientists if more research should be done on the topic is like asking a group of hungry bears if they would like honey. (ETC Group 2011)

The ETC Group seems to be of the opinion that experts with patents is a bigger problem when one single technology cluster is assessed than in more general assessments on how to solve a specific social challenge, such as climate change or global warming. In order to shed light on this statement I would then expect to find more patent-holders in reports addressing one specific technology than in the reports investigating mitigation.

\section{Sources}

The current paper examines all the contributors to IPCC WG III Climate Change 2014: Mitigation of Climate Change (IPCC 2014b) and Carbon Capture and Storage (IPCC 2005), as well as all the contributors to the IPCC Expert Meeting on Geoengineering (IPCC 2012b) and the contributors to the chapters on geoengineering in IPCC WG I Climate Change 2013 - The Physical Science Basis (IPCC 2014a). The contributors total 650 authors, editors, and reviewers with different degrees of responsibility and influence. The reason for limiting the study to two chapters in WG I 2013 is to create a basis for comparison due to the extensive treatment of climate technologies in the other reports. It is also a pragmatic choice, since there are so many authors on WG I 2013.

The second main source is the World Intellectual Property Organization's (WIPO) database of patents available on http://patentscope.wipo.int/search/en/search.jsf. I followed the method outlined by Krimsky et al. (1999) by collecting all the authors' names from the IPCC reports and matching this list of authors with WIPO-listed patents and patentapplications filed prior to the publication of the relevant IPCC reports. I supplemented this with searches in Google's patent base: https://www.google.com/?tbm=pts. I singled out the patents granted or patent-applications filed with a connection to climate technologies. I have included patents relating to chemical processes; oil, coal, and gas extraction; carbon dioxide treatment, transport, and storage; solar radiation management; carbon dioxide removal; and services related to all these activities. The patent holders were sorted by chapter and for the reports as a whole.

Patents can be granted by a national, regional or international entity, such as the Norwegian Patent Board, the European Patent Office or through the PCT (Patent Cooperation Treaty) administered by WIPO (OECD 2009). Patents for the same invention can be granted by several different national or regional patent offices. In order to avoid counting the same patent several times, I chose to systematize the patents first according to the WIPO-administered patents and then by adding nationally or regionally-filed patents.

\section{The IPCC reports}

The percentages and absolute numbers of patent-holders will be presented first in total distri- 
buted for all the reports in Table 1, and then I will move on to present single chapters and thematic sections of the reports in Tables 2 and 3.

Table 1: Overview of patent-holders in IPCC WGs: ${ }^{1}$

\begin{tabular}{|l|l|l|l|l|}
\hline & $\begin{array}{l}\text { IPCC WG } \\
\text { III CCS } \\
\text { (IPCC } \\
2005)\end{array}$ & $\begin{array}{l}\text { IPCC } \\
\text { Geoengineering } \\
\text { (IPCC 2012b) }\end{array}$ & $\begin{array}{l}\text { IPCC WG I } \\
\text { Geoengineering } \\
\text { chapters (IPCC } \\
\text { 2014a) }\end{array}$ & $\begin{array}{l}\text { IPCC WG } \\
\text { III (IPCC } \\
\text { 2014b) }\end{array}$ \\
\hline Persons in the writing team & 140 & 67 & 151 & 271 \\
\hline Mean number of patents & 0.7 & 0.1 & 0.1 & 0.8 \\
\hline Max. number of patents & 21 & 4 & 4 & 89 \\
\hline Median number of patents & 0.0 & 0 & 0.0 & 0.0 \\
\hline Persons with patents persons with & 27 & 2 & 6 & 16 \\
\hline $\begin{array}{l}\text { Percentage } \\
\text { patents }\end{array}$ & $19.3 \%$ & $3.0 \%$ & $4.0 \%$ & $5.9 \%$ \\
\hline Total patents person with & 3.8 & 3 & 13 & 206 \\
\hline $\begin{array}{l}\text { Patents per } \\
\text { patent pren }\end{array}$ & 2.2 & 12.9 \\
\hline
\end{tabular}

Table 2: Patent-holders in Mitigation of Climate Change (IPCC 2014b) distributed by chapter

\begin{tabular}{|l|l|l|l|}
\hline Chapters in IPCC WG III 2014 & $\begin{array}{l}\text { Patent } \\
\text { holders }\end{array}$ & $\begin{array}{l}\% \text { experts } \\
\text { with } \\
\text { patents }\end{array}$ & $\begin{array}{l}\text { avg. } \\
\text { patents } \\
\text { per } \\
\text { patent } \\
\text { holder }\end{array}$ \\
\hline Introductory Chapter & 0 & $0 \%$ & 0 \\
\hline $\begin{array}{l}\text { Integrated Risk and Uncertainty Assessment of Climate } \\
\text { Change Response Policies }\end{array}$ & 1 & $8.3 \%$ & 1 \\
\hline Social, Economic and Ethical Concepts and Methods & 0 & $0 \%$ & 0 \\
\hline Sustainable Development and Equity & 1 & $7.1 \%$ & 1 \\
\hline Drivers, Trends and Mitigation & 1 & $5.6 \%$ & 1 \\
\hline Assessing Transformation Pathways & 0 & $0 \%$ & 0 \\
\hline Energy Systems & 1 & $4.8 \%$ & 13 \\
\hline Transport & 3 & $18.8 \%$ & 24.7 \\
\hline Buildings & 5 & $29.4 \%$ & 20.8 \\
\hline Industry & 2 & $13.3 \%$ & 5 \\
\hline Agriculture, Forestry and Other Land Use (AFOLU) & 0 & $0 \%$ & 0 \\
\hline Human Settlements, Infrastructure and Spatial Planning & 1 & $6.3 \%$ & 1 \\
\hline $\begin{array}{l}\text { International Cooperation: Agreements } \\
\text { Instruments }\end{array}$ & 0 & $0 \%$ & 0 \\
\hline Regional Development and Cooperation & 0 & $0 \%$ & 0 \\
\hline National and Sub-National Policies and Institutions & 1 & $5.9 \%$ & 1 \\
\hline Cross-cutting Investment and Finance Issues & 0 & $0 \%$ & 0 \\
\hline Total for whole report & 16 & $5.9 \%$ & 12.9 \\
\hline
\end{tabular}


From these numbers, it seems clear that with $19.3 \%$ patent-holders on the writing team of the CCS report from 2005, the hypothesis is that single technology assessments have a large presence of patent-holders among their contributors. However, the parts from WG I (2013) and the Geoengineering report (2011) contradict this hypothesis when compared to the higher presence of patent-holders in WG III (2014). When studying the mean number of patents, it seems that the WG III reports ( 0.7 and 0.8 patents per author) score more highly than both the composed group and the WG I ( 0.1 and 0.1 patents per author). The percentage of persons with patents is nevertheless rather similar between WG III (2014) and the composed group and the WG I. In total, there are a large number of patents on the WG III report teams.

Looking at the different parts of the reports from WG III gives the image of a diversified composition with regards to patents (see Table 2 above).

Table 3: Patent-holders in Carbon Capture and Storage (IPCC 2005) distributed by chapter

\begin{tabular}{|l|l|l|l|}
\hline Chapter in IPCC 2005 & $\begin{array}{l}\text { Patent } \\
\text { holders }\end{array}$ & $\begin{array}{l}\% \text { experts } \\
\text { with } \\
\text { patents }\end{array}$ & $\begin{array}{l}\text { avg. } \\
\text { patents } \\
\text { per patent } \\
\text { holder }\end{array}$ \\
\hline Introduction & 0 & $0 \%$ & 0 \\
\hline Sources of $\mathrm{CO}_{2}$ & 0 & $0 \%$ & 0 \\
\hline Capture of $\mathrm{CO}_{2}$ & 9 & $37.5 \%$ & 2.9 \\
\hline Transport of $\mathrm{CO}_{2}$ & 3 & $33.3 \%$ & 3 \\
\hline Underground geological storage & 6 & $16.7 \%$ & 2.7 \\
\hline Ocean storage & 2 & $11.1 \%$ & 1 \\
\hline $\begin{array}{l}\text { Mineral carbonation and industrial uses of } \\
\text { carbon dioxide }\end{array}$ & 8 & $72.7 \%$ & 6 \\
\hline Cost and economic potential & 2 & $12.5 \%$ & 4.5 \\
\hline $\begin{array}{l}\text { Implications of carbon dioxide capture and } \\
\text { storage for greenhouse gas inventories and } \\
\text { accounting }\end{array}$ & 0 & $0 \%$ & 0 \\
\hline Total for whole report & 27 & $19.3 \%$ & 3.8 \\
\hline
\end{tabular}

In both these reports, there are chapters with a large number of patent-holders. The chapters with a large number of patent-holders can be characterized as those relating to transport, building and industry. These are not areas that are directly involved in mitigation or fossil fuel extraction, but rather with the use of products emitting greenhouse gases. This seems to suggest that the majority of patent-holders do not have links to the implementation of mitigation technologies as such, but are involved in industrial sectors closely connected to the production and infrastructure of goods and services.

Table 4: Patent-holders in Carbon Capture and Storage (IPCC 2005) and Mitigation of Climate Change (IPCC 2014b) distributed

\begin{tabular}{|l|l|l|l|}
\hline $\begin{array}{l}\text { Percentage patent } \\
\text { holders in / on }\end{array}$ & social issues & technical issues & policy and finance \\
\hline IPCC CCS 2005 & N/A & $22.8 \%$ & $7.7 \%$ \\
\hline IPCC WG III 2014 & $3.7 \%$ & $11.8 \%$ & $2.4 \%$ \\
\hline
\end{tabular}


For the WG III reports, it is further possible to group some of the chapters together under the headings "social issues", "technical issues", and "policy and finance" as presented in Table 4. The numbers in Table 4 suggest that until now there has been a constant and large presence of persons with patents in the WG III technical parts, and - surprisingly - this presence has moved into chapters related to social issues. Since there are few indications of any relationship between the assessment of a specific technological cluster and patents, the large presence of patent-holders on the IPCC WG III report on CCS must be understood in a different light. If we look at the assessment of geoengineering technologies in WG III 2014, (in "Assessing Transformation Pathways" and "Agriculture, Forestry and Other Land Use (AFOLU)"), there is no one holding a patent. The material suggests that there are more likely to be many patent-holders on issues of infrastructures, industry and transport than for single technologies.

\section{Patents}

Patents are legal constructs. According to WTO's Agreement on Trade-Related Aspects of Intellectual Property Rights, patents "shall be available for any inventions, whether products or processes, in all fields of technology, provided that they are new, involve an inventive step and are capable of industrial application" (WTO 1994).

Patents are part of a family of legal instruments known as intellectual property (IP). This family also includes Copyright and Related Rights, Trademarks, Industrial Design and Integrated Circuits, Geographical Indications, and Protection against Unfair Competition (WIPO 2004).

The patenting system is part of the larger international regulation on intellectual property. The World Intellectual Property Organization lists two main reasons for countries to protect intellectual property:

1. to give statutory expression to the moral and economic rights of creators in their creations and the rights of the public in access to those creations.

2. to promote, as a deliberate act of Government policy, creativity and the dissemination and application of its results and to encourage fair trading which would contribute to economic and social development (WIPO 2004: $3)$.

The patent itself is a document issued by the competent government office, based upon an application procedure. This document describes an invention. The issuing of a patent grants the applicant the rights to commercial exploitation of the described invention for a fixed period, but the patent-holder must disclose the invention in order to let other people benefit from it. The patent-holder also has the right to allow other people to use the invention development (WIPO 2004).

All types of IP, including patents, are legal instruments in the field of jurisprudence. The characteristic approach to discussing ethics and patenting has been to discuss whether "gene patents confer 'ownership' of part of our natural heritage, disturb ethical balances, improperly restrict research and experimentation, and even violate human dignity" (Crespi 2005: 119). Patents are further studied in innovation studies where the role of patents as drivers of knowledge is emphasized (Walsh, Arora \& Cohen 2003). The function of patents as units for geographical knowledge transfer is recognized (Jaffe, Trajtenberg \& Henderson 2002). The issue of patents in sciences has also been extensively studied within the biomedical and pharmaceutical industries (Nogués 1990; Heller \& Eisenberg 1998). 
In legal terms, a patent constitutes what is referred to as a "negative right" which means that the filer of the patent is granted protection from others utilizing the invention for commercial purposes for a limited time and in a defined place, while the patent-holder renders the knowledge into the public domain (Foray 2004). The understanding of what a patent "really is" depends in many ways on a series of contextual assumptions and conditions. As a legal entity, patents are a part of property law, and more precisely intellectual property law. Patents performatively create a non-rival public good, knowledge, and a private good, property. Under the current intellectual property regime, the alternatives to the knowledge dimension of patents would range somewhere between open source and secrecy, while the proprietary dimension would range from free competition to governmental dictate. However, there might be some attractive options within this range (Foray 2004).

For the individual inventor or holder of a patent, it is often a long journey from the described process, method or invention to the actual production and marketing of a product based upon a given patent. Such actualization depends on licensing agreements or other contractual relationships with a producer. Dave Guston documents the different motivations for (or against) patenting and the serendipities connected to patenting. In his TTO case study, Guston (1999: 99) shows how practical concerns matter: "Patents can help secure the priority and integrity of a discovery, and can facilitate the reduction of such discoveries to clinical practice". Others believe that "public funded research should remain public" (Guston 1999: 99). Guston also mentions that it is not obvious that a researcher actually knows when she or he has made a discovery or an invention.

Ingrid Schneider characterizes the legal epistemic community as "gatekeepers" that "are keeping other disciplines and considerations from entering into political deliberation" (2009: 621). Kica and Groenendijk (2011) describe the wider societal system surrounding the current procedures for granting patents based on changing political, social, and technical developments. Similar issues, like "Academic Capitalism", "Science Inc.", ... etc. are frequently raised and allude to a situation where academia produces knowledge (uniquely) for economic purposes and that resulting distribution of the economic gains contribute to unfairness (Nowotny 1993; Slaughter \& Leslie 1997; Krimsky 2003; Slaughter \& Rhoades 2004; Hackett 2014). Voices are also raised that conclude that "the norm of communism is being or has been replaced by the norm of private intellectual property" (Metlay 2006: 566). This reference to a rupture with Robert Merton's (1973) norms of (and for) science signals an understanding that the terms and conditions in "the social contract for science" are changing (Gibbons et al. 1994). As a response or countermeasure to such changes, Owen, Macnaghten and Stilgoe (2012) propose to move to "science for society, with society". This article also looks at patents in the interface between science and society.

\section{Conflicts of Interest and the IPCC}

In order for this paper to present an argument that there is a conflict of interest for patentholders on the IPCC-CCS team, it is not only necessary to present an understanding of what a conflict of interest is, but also to provide arguments that the IPCC panels are institutions where conflict of interest can take place. I will begin with the first.

\section{Conflicts of Interest}

Let us say that a person, Eric, is put by his superior in a bank onto a public committee to oversee financial policies. If Eric defends his bank's interests on this committee instead of 
addressing the common good, Eric is not in a conflict of interest. Eric's primary interest as the bank's representative ought to be the bank's interest. On the same committee there is a professor in economics, Elliott, from the country's largest university. Elliott has 1,000,000 Euros worth of shares in Eric's bank, and he does not share this information with the organizers or anyone on the committee. Elliott is appointed solely as an expert in economics. Elliott and Eric agree on every issue of the committee. Whereas Eric's primary interest corresponds with his bank's interests, Elliott's primary interest should be scholarly, but since Elliott also has a secondary financial interest in the proceedings of the committee, there is a risk that he bases his decisions on his private financial considerations rather than his academic concerns. It is the risk that a person's primary interests conflict with secondary interests that Dennis F. Thompson (2009) defines as a conflict of interest. A conflict of interest is not the same as corruption or foul play, but it is "a set of circumstances that create or increase a risk that primary interests will be compromised as a result of the pursuit of secondary interests" (Thompson 2009: 137). If Elliott actually agrees with Eric on all issues because he wants to profit on his stocks, it is no longer a conflict of interest, but the victory of the wrong interests.

\section{The IPCC policy on Conflicts of Interest}

The "Climategate" scandal in 2009 triggered a series of reactions towards IPCC. "Climategate" is the term used for the publication of hacked emails from the Climate Research Unit at the University of East Anglia. According to the hackers and the persons disseminating the emails, they proved the falsity of the so-called hockey-stick-graph showing temperature rise (Ryghaug \& Skjølsvold 2010). The IPCC started reviewing its internal policies after the assessment report by the InterAcademy Council. The report suggested that "[t]he IPCC should develop and adopt a rigorous conflict-of-interest policy" (InterAcademy Council 2010: 53) since the IPCC lacked such a policy - as did the Millennium Ecosystem Assessment and the Global Biodiversity Assessment - while both the UNEP and the WMO had such policies. The InterAcademy Council suggested among other issues that the IPCC include features such as:

Considering a range of relevant financial interests, such as employment and consulting relationships; ownership of stocks, bonds, and other investments; fiduciary responsibilities; patents and copyrights; commercial business ownership and investment interests; honoraria; and research funding (InterAcademy Council 2010: 53).

In the InterAcademy report, it is stated that one concern for such a conflict of interest was the IPCC Chair's alleged work for an energy company. The IPCC began working on the CoIpolicy in October 2010 (Beck 2012). In the aftermath of "Climategate", Transparency International (2011) published a special report on climate change, but without addressing patents by IPCC panel members even though they acknowledge that the "mismatch between the supply and demand of specialized skills means that key experts end up wearing multiple hats and the potential for conflicts of interests grows" (Transparency International 2011: xxxiv). Transparency International sees only that "[c]onflict of interest is a pervasive corruption risk in climate governance at the international and national level" (2011: 10) without addressing the transnational level of the IPCC.

The Intergovernmental Panel on Climate Change (IPCC) adopted its conflict of interest policy in November 2011, and working methods for the Conflict of Interest Committee in 2012 (IPCC 2012a). These policies will be applicable for all future panelists, and apply to all 
IPCC senior personnel. The policy does not apply retroactively (The Economist 2011). The policy concerns all IPCC products and will be executed according to the levels of authority and responsibility in the IPCC process. The definition of "conflict of interest" from the IPCC CoI policy is as follows:

11. A "conflict of interest" refers to any current professional, financial or other interest which could: i) significantly impair the individual's objectivity in carrying out his or her duties and responsibilities for the IPCC, or ii) create an unfair advantage for any person or organization. For the purposes of this policy, circumstances that could lead a reasonable person to question an individual's objectivity, or whether an unfair advantage has been created, constitute a potential conflict of interest. These potential conflicts are subject to disclosure (IPCC 2011).

The IPCC distinguishes between bias and CoI. Bias is understood as a certain perspective from which a given view is believed to be correct, but where there is no personal gain at stake. Among the interests that should be disclosed by IPCC associates are:

Employment relationships; consulting relationships; financial investments; intellectual property interests; and commercial interests and sources of private-sector research support. Individuals should also disclose significant and relevant financial interests of any person with whom the individual has a substantial business or relevant shared interest (IPCC 2011).

In this article, the salient issues will be "intellectual property rights" (IPR). The IPCC states unequivocally that the disclosure of a CoI is not sufficient (albeit necessary) to participate in the IPCC. The CoI must be resolved, according to the IPCC.

Nevertheless, there is also the possibility of looking at the CoI issue from the opposite side: did the researchers on the IPCC reports have a moral or legal obligation to inform the IPCC or the recipients of the IPCC report of their CoI? According to the Institute of Medicine, National Academy of Sciences, and National Academy of Engineering (1995: 8-9) it is the individual scientist's own duty to inform editors of "financial interest in a particular company". Whereas the IPCC could not know directly whether a scientist held patents, the scientists had such knowledge and should have known that it is common to be expected to disclose interests.

\section{Is disclosure a silver bullet?}

Let us imagine that Elliott disclosed his shares in the bank. Would that alleviate a CoI? Here, the case is unsettled. On one side, Bariani et al. conclude that in the case of oncology trials and self-reported CoI, the "interpretation of recently published phase III cancer trials by their authors or by editorialists was not influenced by financial relationships or industry sponsorship. Increased awareness of CoI policies may have led to more integrity in cancer research reporting" (Bariani et al. 2013: 2289). Based on a review of the American Psychiatric Association's compilation of the latest Diagnostic and Statistical Manual of Mental Disorders, Cosgrove and Krimsky (2012) argue that disclosure of CoI might be understood as generally absolving the person in question from the responsibility of handling the CoI. Further, Cosgrove and Krimsky express concerns that where experts with financial ties are included, disclosing the full extent of these connections might lead to an overload of information that creates difficulties in finding the relevant information. Lastly, they quote an earlier finding 
from Krimsky that a one-sided emphasis on disclosure "shifts the problem from one of 'secrecy of bias' to 'openness of bias"' (2010: 108). Based on a study of drug regulatory agencies, Lexchin and O'Donovan (2010) argue that the precautionary principle should be applied in cases of CoI. In their understanding, disclosed CoI places new and administrative burdens on organizations in the form of decision-making risk management.

Disclosure might have a positive effect on the risk of secondary interest influencing the primary interest, i.e. the risk diminishes, but even this reduced risk has to be managed. However, disclosure might also create new problems of perceived personal responsibility, irrelevant information, and might mean that open bias remains a bias.

\section{The relationship between expertise and patents}

Transparency International (2011: xxxiv) addresses the central issue that "key experts end up wearing multiple hats and the potential for conflicts of interests grows". To understand the issue of experts holding patents and simultaneously providing policy advice, one needs to understand if it is the case that there is a correlation between level of expertise, patents, and advisory roles.

Gulbrandsen and Smeby (2005: 944) find that "[p]atents are positively correlated with academic position" for Norwegian scientists. Meyer (2006) confirms this finding for nanoscientists, and Tsai-Lin et al. (2013) show that it also applies for Taiwan. Patenting could then - as a heuristic rule - be understood as corresponding to the epistemic quality of the expertise. One important factor will then be if we have reason to believe or to doubt that the IPCC report-writing and reviewing teams are the top experts. The selection of authors and review editors for the WG I Fifth Assessment Report (AR5) was completed in June 2010 (IPCC 2014c). The InterAcademy Council presented its evaluation and recommendations on 30 August 2010, where it noted that the "absence of a transparent author-selection process or well-defined criteria for author selection can raise questions of bias and undermine the confidence of scientists and others in the credibility of the assessment" (2010: 15). Since 2010, the IPCC has worked to ameliorate its selection processes (IPCC n.d.).

The relationship between high level of expertise and participation in patented inventions seems clear. The relationship between high level of expertise and participation on IPCC reports is not transparent. However, if expert advisory groups - where the selection process is open, transparent and well-defined - are to include the best scientists, then a certain percentage of patent-holders from academia, business or international organisations will be expected.

\section{Conflicts of interest and views on the contract between science and society}

The IPCC is a large institution that can be studied from many aspects (Hulme \& Mahony 2010). In the current study, I will limit myself to look at the IPCC as a scientific organization that has an impact on policy. Since the IPCC now has a conflict of interest policy, it seems reasonable to suggest that conflicts of interests might occur. However, it remains to be understood whether the IPCC should be subject to CoI policies because it is a scientific institution or because it is a political institution. The relationship between science and policy can be understood using the principal agent theory, where the principal, a policy-maker, requests some agent - in this case a science panel - to perform a specified task that the principal is not able to perform directly (Guston 1996). In such a case, scientific advice needs to give an answer to the principal that meets the current standards for transparency in political affairs, since the scientific advice can be seen as contributing to the political pool of knowledge. 
The relationship between science and policy can also be described through the linear model of expertise - or the speaking truth to power paradigm - where the "influence of science on policy is assumed to be strong and deterministic: if the scientific facts are 'sound,' then they have an immediate, direct impact on policy" (Beck 2011:298). The antecedent here demands that the facts shall be "sound;" and soundness is in turn determined by the steps in the scientific procedure, according to philosophical logic: "an inference is normally termed 'sound' if, and only if, the logical form of the argument is valid (i.e., truth preserving) and all its premises are true" (Kaiser et al. 2007: 66). As in the example with Elliot above, there is an increased risk that someone holding patents might present skewed premises, misleading connections, or both.

If we address the relationship between science and policy from the perspective of a coproduction of knowledge between science and society, we would expect to find interactions between the two spheres (Hulme 2009; Jasanoff 2004). Here one would investigate the issues of great relevance to the public and focus on societal goals. The outcome and the goal are here a hybrid product where neither of the epistemic realms are given priority, and "the more we blur them the more transparent science policy becomes" (St Clair 2006: 64). On the surface, it could seem that a committed co-production would be a process where the results of CoI might be annulled. However, the scope of the patent from a patent-holder's perspective is not primarily to share the knowledge. The sharing of knowledge might be seen as society's demand on science for being given a monopoly on the earnings. There is then an increased risk that the brokering from the patent-holder is not honest and transparent. Sheldon Krimsky (2003: 52) writes: "Finding a way to avoid even the appearance of a conflict is one of the principal challenges in establishing universities as an honest broker". Helga Nowotny goes even further and in inflammatory language attacks violations against the public nature of science:

The full transparency of obtaining reliable knowledge about nature and for the benefit of society is the reason why misconduct, dishonesty, and fraud are regarded not only as deviant, but also as endangering the claim to the autonomy and self-governance of science. A system that totally depends upon mutual openness, honesty, and trust elicits strong reactions against those who violate these principles, and it must strive to restore credibility as quickly as possible (Nowotny 2005: 7).

The notion of a co-production seems to be teleological, with specific demands on the procedure to reach the articulated goals. In the vocabulary of Jan Schmidt (2011), one could say that the problem-orientation and the consequent knowledge-production of the science system is bifurcated when patents are involved, since when patents exist, a commitment to the patented solution already exists - regardless if there might be commitments to other social contributions. In such settings, Schmidt (2011: 259) argues that "otherwise democratic societies [...] turn into expertocraties".

Regardless of which model for science-policy interaction is used, either prescriptively or descriptively, for the IPCC, the presence of patent-holders on the panels is a signal of conflicts of interest.

\section{Conflict of interest and funding bias}

Science for policy is different from science for the sake of science. Political decisions on the mitigation of climate change concern potentially huge sums of public and private money. According to Funtowicz and Ravetz, "[p]olicy-makers tend to expect straightforward 
information as inputs to their decision making process; they want their numbers to provide certainty" (1990: 7).

In research ethics, the term "funding bias" refers to how "private funding can bias the outcome of studies toward the interests of the sponsors" (Krimsky 2003: 146). Such funding bias can be found in areas of research as diverse as criminology (Geis et al. 1999), food (Massougbodji et al. 2014), medicine (Davidson 1986), public health (Mandeville et al. 2013), and marine mammal research (Wade et al. 2010). These studies have all documented how, through statistical analysis of funding seen in relation to outcome, one can detect clear patterns that indicate that the source of the funding had aggregated effects on the outcome of the studies. The scope of these studies has not been to show that researcher $\mathrm{X}$ or project $\mathrm{Y}$ is flawed, but rather that there is an increased risk of funding bias in sponsored research.

The relevance for such "funding bias" in relation to the IPCC's way of working should be clear: in the IPCC review processes, no research is conducted by the IPCC itself, so the report functions as an external review of the material (Funtowicz \& Ravetz 1990: 163). The authors, who are scientists, review already published material and do not start with new research projects on behalf of the IPCC. Here, the double risk exists of a funding bias in the reviewed articles and a funding bias in the reviewers; the peer-review process can then create higher likelihoods for CoI with the ensuing higher risks. The source of the bias might consequently benefit from a potentially biased process.

\section{What is the relationship between patents and Col}

In most countries, national laws and regulations, as well as local agreements, exist on how the potential financial gain shall be divided between an inventor and the employer. In Luis Alvarez's (1987) autobiography, we can read about how in the years after World War II, state employees received \$ 1 in compensation for creating a successful patent - and further income went to the state. In order to create incentives for more knowledge-drive innovation, the US congress promulgated what is today known as the Bayh-Dole Act in 1980. This legislation gives universities the right to patents; its intention was to stimulate cooperation between academia and industry, and this cooperation created ties that might qualify as CoI (Schacht 2006). Since patents grant their holder the economic rights over the invention, a patentholder has an economic interest in the realization of the patent. If all the rights to income from the patents have been transferred from the academic inventor to her or his institution, then the institution has an interest in the patent being commercially successful:

However, the institutions themselves are also in a situation of conflicting interests to the extent that institutions also collect a share of industry research grants and royalties from patents generated by their faculty (Cho et al. 2000: 2204).

Consequently, as illustrated in my example above, employees of a given institution also have an interest in the success of their institution, regardless of whether or not they are specifically remunerated for an invention for which they have transferred the rights to their employer. For the sake of this paper, I will not investigate the different policies regarding transfer of patents to academic institutions, but persist in the position that if a person is listed as inventor or holder of a patent, then that person has an interest in the commercial exploitation of that patent. An even stricter line could be imagined: it would be possible to claim that an employee in an organization holding patents has an interest in the realization of the patent regardless of whether or not that employee has a direct connection to the patent. 
A person having one or several patents, who is on an IPCC writing team, might use his or her discretionary power and scientific judgment in the best possible way. However, there is an increased risk that such patents might increase the likelihood that science is unduly influenced.

\section{IPCC reports and conflicts of interest}

Much thinking and many policies concerning CoI have been directed towards public civil servants or private employees both in national and international settings (Malonga 2012). In public settings, conflicts of interest might arise when there is a possibility that a private interest might interfere with the public interest, but also when competing public interests are in danger of interfering with a public decision-making process (Auby 2012: 147). So when reading the IPCC CoI policy, one needs to take into account that not only private interests can impair an individual's objectivity, but also competing public interests can. If the IPCC report writers are convinced that mitigating climate change is a virtuous issue, then they also run the risk of what has been called White Hat Bias (WHB). This is defined as "bias leading to distortion of information in the service of what may be perceived to be righteous ends" and has been found to "consistently [be] pushing conclusions in a single direction and systematically distorting the research record" (Cope \& Allison 2010: 1615).

The actors that can be in a CoI situation are all the actors in the administrative field. JeanBernard Auby (2012: 146-147) mentions four different groups:

1. Ministers, government executives, and top civil servants

2. Members of local governments, administrative committees, or other collegial bodies

3. Judges involved in administrative issues

4. Private persons taking part in administrative functions.

In this fourth and last group, we also find experts who are consulted in a public administrative matter or private companies that execute outsourced public tasks. Drawing upon Peter Haas' (1992) understanding of experts as being created and creating "epistemic communities", René Urueña (2012) addresses an important paradox of expert CoI: "regulation (and control) of expert power in global governance is dependent in its legitimacy on the very expertise it tries to regulate and control" (Urueña 2012: 85). Keeping in mind Haas's (1992: 3) understanding of an epistemic community in which members share the "belief or faith in the verity and the applicability of particular forms of knowledge or specific truths," Urueña makes an important point in underlining that the legitimacy of expertise in global/international issues is different from domestic expertise, as the latter is legitimized by parliamentary procedural justice while the former rests upon the expertise in itself. Global governance can thus be understood as more dependent upon the "epistemic communities."

One question remains unanswered. Thus far, I have documented the presence of patentholders on the WG III reports. I have not documented that they actually have a CoI. On the WG III, there is a mix of academics, industry, government and (i)NGOs. Split in this manner, we see that the large majority of patent-holders are academic, that is, they are listed in the annex as belonging to a university or research institution. The numbers for the IPCC CCS (IPCC 2005) are listed in Table 5: 
Table 5: Patent-holders in Carbon Capture and Storage (IPCC 2005) distributed by institutional affiliation

\begin{tabular}{|l|l|l|l|}
\hline Role & No. participants & $\begin{array}{l}\text { Persons with } \\
\text { patents }\end{array}$ & $\begin{array}{l}\text { Percentage with } \\
\text { patents }\end{array}$ \\
\hline Government & 27 & 1 & $3.7 \%$ \\
\hline Academia & 76 & 19 & $25 \%$ \\
\hline NGO & 6 & 0 & $0 \%$ \\
\hline $\begin{array}{l}\text { International } \\
\text { organization }\end{array}$ & 5 & 0 & $0 \%$ \\
\hline Business & 26 & 7 & $26.9 \%$ \\
\hline
\end{tabular}

There is a slight over-representation of patent-holders from business as seen in relation to the academics with $26.9 \%$ versus $25 \%$. As illustrated in Table 6, the trend is similar in the WG III report from 2014 with a large number of academics, but the percentage of patent-holders from business is larger.

Table 6: Patent-holders in Mitigation of Climate Change (IPCC 2014b) distributed by institutional affiliation

\begin{tabular}{|l|l|l|l|}
\hline Role & No. participants & $\begin{array}{l}\text { Persons with } \\
\text { patents }\end{array}$ & Percentage with patents \\
\hline Academic & 226 & 14 & $6.2 \%$ \\
\hline Government & 14 & 0 & $0 \%$ \\
\hline Business & 12 & 2 & $16.7 \%$ \\
\hline $\begin{array}{l}\text { International } \\
\text { organization }\end{array}$ & 18 & 0 & $0 \%$ \\
\hline
\end{tabular}

The numbers here seem to indicate a presence, and a considerable one in 2005, of secondary interests on the IPCC report teams among supposedly neutral academics. It could further be argued that since the IPCC reports are presented by the IPCC as scientific assessments - and not stakeholder-based assessments - even the presence of representatives from business who hold patents could be somewhat misleading since the reports claim to be based only on epistemic values (Betz 2013).

\section{Conclusion}

The review of experts with patents on IPCC writing teams suggests that the presence of patent-holders is largest on issues of infrastructure, industry and transport rather than for single technologies or technological clusters. The alarm struck by the ETC Group and other signatories before the IPCC joint working group expert meeting on geoengineering in June 2011, however, is not without justification since, at that time, there was a discussion within the IPCC on the CoI policy. The ETC Group's concerns seem to apply to the Carbon Capture and Storage report (2005), but it is not possible to extrapolate from this report to geoengineering.

The presence of experts who might hold secondary interests to the IPCC's mandate of assessing the physical aspects of climate change, the vulnerability to climate change and the options for mitigation, can to a certain extent be analyzed by the notion of a CoI. The 
strongest case for applying CoI as a tool to address the presence of patent-holders in the IPCC is when these experts are listed as university-affiliated academics in the reports. The case for experts from business is more difficult, since they can legitimately be seen as also representing an important stakeholder perspective.

This article has shown that the issue of intellectual property and its relation to policy advice is a difficult one, and even more so in the context of international policy advice. The occurrence of funding bias in national contexts might not be transferable to international contexts. At national and at university or institutional level, the committees for research ethics serve to arbitrate on CoI. On the global scale, and for transnational institutions like the IPCC, such arbitration instances do not exist.

\section{Acknowledgements}

I wish to thank the reviewer for clear advice and sound challenges. Further, I thank EllenMarie Forsberg, Anders Braarud-Hanssen, Fern Wickson, Clive Hamilton and Arie Rip for generous and insightful assistance and encouragement at different stages and in their unique ways. The support from Erlend Hermansen and Mads Dahl Gjefsen has also been much appreciated.

\section{Note}

${ }^{1}$ The surplus information and categories in Table 1 are included to assist in further research.

\section{References}

Alvarez, L. W. (1987). Alvarez: Adventures of a Physicist. New York: Basic Books.

Auby, J.-B. (2012). Conflict of interest and administrative law. In Peters, A. \& Handschin, L. (eds.) Conflict of Interest in Global, Public and Corporate Governance, pp. 145-158. Cambridge: Cambridge University Press.

Bariani, G. M., de Celis Ferrari, A. C. R., Hoff, P. M., Krzyzanowska, M. K. \& Riechelmann, R. P. (2013). Self-reported conflicts of interest of authors, trial sponsorship, and the interpretation of editorials and related phase III trials in oncology. Journal of Clinical Oncology: Official Journal of the American Society of Clinical Oncology, 31 (18): 22892295.

Beck, S. (2011). Moving beyond the linear model of expertise? IPCC and the test of adaptation. Regional Environmental Change, 11 (2): 297-306.

Beck, S. (2012). Between Tribalism and Trust: The IPCC Under the" Public Microscope". Nature and Culture, 7 (2): 151-173.

Betz, G. (2013). In defence of the value free ideal. European Journal for Philosophy of Science, 3 (2): 207-220.

Cho, M. K., Shohara, R., Schissel, A. \& Rennie, D. (2000). Policies on faculty conflicts of interest at us universities. JAMA, 284 (17): 2203-2208.

Cope, M. B. \& Allison, D. B. (2010). White hat bias: a threat to the integrity of scientific reporting. Acta Podiatrica, 99 (11): 1615-1617.

Cosgrove, L. \& Krimsky, S. (2012). A Comparison of DSM-IV and DSM-5 Panel Members' Financial Associations with Industry: A Pernicious Problem Persists. PLoS Med, 9 (3). 
Crespi, R. S. (2005). Ethico-legal issues in biomedicine patenting: A patent professional viewpoint. Science and Engineering Ethics, 11 (1): 117-136.

Davidson, D. R. A. (1986). Source of funding and outcome of clinical trials. Journal of General Internal Medicine, 1 (3): 155-158.

ETC Group. (2011). Open letter to IPCC on geoengineering (2011/07/29/). http://www.etc group.org/sites/www.etcgroup.org/files/publication/pdf_file/IPCC_Letter_with_Signa tories_-_7-29-2011.pdf

Foray, D. (2004). Economics of knowledge. Cambridge, Mass: MIT Press. 275 pp.

Funtowicz, S. O. \& Ravetz, J. R. (1990). Uncertainty and Quality in Science for Policy. Dordrecht, Netherlands; Norwell, MA, U.S.A.: Kluwer Academic Publishers.

Geis, G., Mobley, A. \& Shichor, D. (1999). Private Prisons, Criminological Research, and Conflict of Interest: A Case Study. Crime \& Delinquency, 45 (3): 372-388.

Gibbons, M., Limoges, C., Nowotny, H., Schwartzman, S., Scott, P. \& Trow, M. (1994). The New Production of Knowledge the Dynamics of Science and Research in Contemporary Societies. London: SAGE Publications.

Gulbrandsen, M. \& Smeby, J.-C. (2005). Industry funding and university professors' research performance. Research Policy, 34 (6): 932-950.

Guston, D. H. (1996). Principal-agent theory and the structure of science policy. Science and Public Policy, 23 (4): 229-240.

Guston, D. H. (1999). Stabilizing the Boundary between US Politics and Science: The Rôle of the Office of Technology Transfer as a Boundary Organization. Social Studies of Science, 29 (1): 87-111.

Haas, P. M. (1992). Introduction: Epistemic Communities and International Policy Coordination. International Organization, 46 (1): 1-35.

Hackett, E. J. (2014). Academic Capitalism. Science, Technology \& Human Values, 39 (5): $635-$ 638.

Heller, M. A. \& Eisenberg, R. S. (1998). Can patents deter innovation? The anticommons in biomedical research. Science, 280 (5364): 698-701.

Hulme, M. (2009). Why We Disagree About Climate Change: Understanding Controversy, Inaction and Opportunity: Cambridge University Press. 427 pp.

Hulme, M. \& Mahony, M. (2010). Climate change: What do we know about the IPCC? Progress in Physical Geography, 34 (5): 705-718.

Institute of Medicine, National Academy of Sciences, and National Academy of Engineering. (1995). On Being a Scientist: Responsible Conduct in Research, Second Edition. Washington, D.C.: National Academy Press.

InterAcademy Council. (2010). Climate change assessments review of the processes and procedures of the IPCC. Amsterdam, The Netherlands: InterAcademy Council.

IPCC. (n.d.) Review of IPCC Processes and Procedures. http://www.ipcc.ch/organization/ organization_review.shtml

IPCC. (2005). IPCC special report on carbon dioxide capture and storage. Cambridge, United Kingdom and New York, NY: Cambridge University Press, for the Intergovernmental Panel on Climate Change. 431 pp.

IPCC. (2011). Decisions taken with respect to the review of IPCC processes and procedures, Conflict of interest policy. IPCC 33rd Session, 10-13 May 2011, Abu Dhabi, UAE, http://www.ipcc.ch/meetings/session33/ipcc_p33_decisions_taken_conflict_of_intere st.pdf 
IPCC. (2012a). Decisions taken with respect to the review of IPCC processes and procedures. Conflict of interest policy. IPCC 35th Session, 6-9 June 2012, Geneva, Switzerland, http://www.ipcc.ch/meetings/session35/IAC_MethodOfWorkCOI.pdf

IPCC. (2012b). Meeting Report of the Intergovernmental Panel on Climate Change Expert Meeting on Geoengineering [O. Edenhofer, R. Pichs-Madruga, Y. Sokona, C. Field, V. Barros, T.F. Stocker, Q. Dahe, J. Minx, K. Mach, G.-K. Plattner, S. Schlömer, G. Hansen, M. Mastrandrea (eds.)]. Potsdam Institute for Climate Impact Research, Potsdam, German: IPCC Working Group III Technical Support Unit. 99 pp.

IPCC. (2014a). Climate change 2013: the physical science basis: Working Group I contribution to the Fifth assessment report of the Intergovernmental Panel on Climate Change. New York: Cambridge University Press. 1535 pp.

IPCC. (2014b). Climate Change 2014: Mitigation of Climate Change. Contribution of Working Group III to the Fifth Assessment Report of the Intergovernmental Panel on Climate Change. Cambridge, United Kingdom and New York, NY, USA: Cambridge Univ Press.

IPCC. (2014c). Questions about the Development of the Report.

Jaffe, A. B., Trajtenberg, M. \& Henderson, R. (2002). Geographic Localization of Knowledge Spillovers as Evidenced by Patent Citations. In Jaffe, A. B. \& Trajtenberg, M. (eds) Patents, citations, and innovations: a window on the knowledge economy, pp. 155-177. Cambridge, Mass: MIT Press.

Jasanoff, S. (2004). Ordering knowledge, ordering society. In Jasanaoff, S. (ed.) States of Knowledge: The Co-Production of Science and the Social Order. New York: Routledge.

Johnson, D. H. (2013). Financial Disclosure, Industry Sponsorship, and Integrity in Cancer Research Reporting. Journal of Clinical Oncology, 31 (18): 2243-2245.

Kaiser, M., Millar, K., Thorstensen, E. \& Tomkins, S. (2007). Developing the ethical matrix as a decision support framework: GM fish as a case study. Journal of Agricultural and Environmental Ethics, 20 (1): 65-80.

Kica, E. \& Groenendijk, N. (2011). The European patent system: dealing with emerging technologies. Innovation: The European Journal of Social Science Research, 24 (1-2): 85-105.

Krimsky, S., Rothenberg, L. S., Stott, P. \& Kyle, G. (1999). Scientific Journals and Their Authors's Financial Interests: A Pilot Study. In Caulfield, T. A. \& Williams-Jones, B. (eds) The commercialization of genetic research: ethical, legal, and policy issues, pp. 101-110. New York: Kluwer Academic/Plenum Publishers.

Krimsky, S. (2003). Science in the private interest: has the lure of profits corrupted biomedical research? Lanham: Rowman \& Littlefield Publ.

Krimsky, S. (2010). Combating the Funding Effect in Science: What's beyond Transparency? Stanford Law \& Policy Review, 21 (1).

Lexchin, J. \& O'Donovan, O. (2010). Prohibiting or 'managing' conflict of interest? A review of policies and procedures in three European drug regulation agencies. Social Science \& Medicine, 70 (5): 643-647.

Malonga, A. N. (2012). Conflict of interest of international civil servants. In Peters, A. \& Handschin, L. (eds) Conflict of Interest in Global, Public and Corporate Governance, pp. 63-84. Cambridge: Cambridge University Press.

Mandeville, K. L., O'Neill, S., Brighouse, A., Walker, A., Yarrow, K. \& Chan, K. (2013). Academics and competing interests in $\mathrm{H} 1 \mathrm{~N} 1$ influenza media reporting. Journal of Epidemiology and Community Health: jech-2013-203128. 
Massougbodji, J., Bodo, Y. L., Fratu, R. \& Wals, P. D. (2014). Reviews examining sugarsweetened beverages and body weight: correlates of their quality and conclusions. The American Journal of Clinical Nutrition, 99 (5): 1096-1104.

Merton, R. K. (1973). The sociology of science: theoretical and empirical investigations. Chicago, Ill.: University of Chicago Press.

Metlay, G. (2006). Reconsidering Renormalization: Stability and Change in 20th-Century Views on University Patents. Social Studies of Science, 36 (4): 565-597.

Meyer, M. (2006). Are patenting scientists the better scholars?: An exploratory comparison of inventor-authors with their non-inventing peers in nano-science and technology. Research Policy, 35 (10): 1646-1662.

Nogués, J. J. (1990). Patents and Pharmaceutical Drugs: Understanding the Pressures on Developing Countries: World Bank Publications. 46 pp.

Nowotny, H. (1993). A New Branch of Science, Inc. In Schomberg, R. V. (ed.) Theory and Decision Library, Science, Politics and Morality, pp. 63-84: Springer Netherlands.

Nowotny, H. (2005). The Changing Nature of Public Science. In Nowotny, H., Pestre, D., Schmidt-Aßmann, E., Schultze-Filitz, H. \& Trute, H.-H. (eds) The Public Nature of Science under Assault, pp. 1-27: Springer Berlin Heidelberg.

OECD. (2009). OECD patent statistics manual. Paris: OECD. 158 pp.

Owen, R., Macnaghten, P. \& Stilgoe, J. (2012). Responsible research and innovation: From science in society to science for society, with society. Science and Public Policy, 39 (6): 751-760.

Ryghaug, M. \& Skjølsvold, T. M. (2010). The Global Warming of Climate Science: Climategate and the Construction of Scientific Facts. International Studies in the Philosophy of Science, 24 (3): 287-307.

Schacht, W. (2006). The Bayh-Dole Act: Selected Issues in Patent Policy and the Commercialization of Technology. Congressional Research Service Reports.

Schmidt, J. C. (2011). What is a problem? Poiesis \& Praxis, 7 (4): 249-274.

Slaughter, S. \& Leslie, L. L. (1997). Academic Capitalism: Politics, Policies, and the Entrepreneurial University. Baltimore, MD: The Johns Hopkins University Press.

Slaughter, S. \& Rhoades, G. (2004). Academic Capitalism and the New Economy: Markets, State, and Higher Education. Baltimore, MD: The Johns Hopkins University Press.

St Clair, A. L. (2006). Global Poverty: The Co-Production of Knowledge and Politics. Global Social Policy, 6 (1): 57-77.

The Economist. (2011, 2011/06/17/17:15). Renewable outrage. The Economist.

Thompson, T. L. (2009). The Applicability of Narrative Ethics. Journal of Applied Communication Research, 37 (2): 188-195.

Transparency International (Ed.) (2011) Global corruption report: climate change. London ; Washington, DC: Earthscan.

Tsai-Lin, T.-F., Chang, Y.-C. \& Katzy, B. R. (2014). "The Longitudinal Impact of Academic Patenting on Publishing Behavior: Evidences from Taiwan (2001-2010)", in 2014 Proceedings of PICMET '14: Infrastructure and Service Integration, pp. 3263-3271.

Urueña, R. (2012). How to start thinking about conflict of interest in global governance? In Peters, A. \& Handschin, L. (eds) Conflict of Interest in Global, Public and Corporate Governance, pp. 85-102. Cambridge: Cambridge University Press.

Wade, L., Whitehead, H. \& Weilgart, L. (2010). Conflict of interest in research on anthropogenic noise and marine mammals: Does funding bias conclusions? Marine Policy, 34 (2): 320-327. 
Walsh, J. P., Arora, A. \& Cohen, W. M. (2003). Effects of Research Tool Patents and Licensing on Biomedical Innovation. In Cohen, W. M. \& Merrill, S. A. (eds.) Patents in the knowledge-based economy, pp. 283-340. Washington, D.C: National Academies Press.

WIPO. (2004). WIPO intellectual property handbook: policy, law and use. Geneva: WIPO.

WTO. (1994). Agreement on Trade-Related Aspects of Intellectual Property Rights. http://www.wto.org/english/tratop_e/trips_e/t_agm0_e.htm 